\title{
Short communication: Effects of feeding sweet sorghum silage on milk production of lactating dairy cows
}

\author{
S. Amer, ${ }^{*}$ P. Seguin, $\dagger$ and A. F. Mustafa* ${ }^{* 1}$ \\ ${ }^{*}$ Department of Animal Science, and \\ †Department of Plant Science, Macdonald Campus, McGill University, Sainte-Anne-de-Bellevue, Quebec, Canada H9X 3V9
}

\begin{abstract}
The objective of this study was to determine the feeding value of sweet sorghum silage (SS) for dairy cows compared with alfalfa silage (AS). Two diets were formulated with a 50:50 forage:concentrate ratio. Sweet sorghum silage and AS constituted $70 \%$ of the forage in each diet (dry matter basis). Twelve lactating Holstein cows in early lactation were used in a crossover experiment. Relative to AS, SS contained $58 \%$ more neutral detergent fiber and 36.6 and $72.7 \%$ less acid detergent lignin and crude protein, respectively. Milk yield (33.0 vs. $36.7 \mathrm{~kg} / \mathrm{d}$ ) was lower for cows fed SS than for those fed AS. However, dry matter intake, energy-corrected milk, and feed efficiency were similar for both dietary treatments. Replacing AS with SS increased concentrations of milk fat (4.44 vs. $3.80 \%)$ and total solids (13.31 vs. $12.88 \%)$ and reduced concentrations of milk lactose (4.55 vs. $4.61 \%$ ), milk solids-not-fat (8.88 vs. $9.08 \%$ ), and milk urea nitrogen (10.0 vs. $14.0 \mathrm{mg} / \mathrm{dL})$. We concluded that replacing AS with SS had negative effects on milk yield, whereas dry matter intake, energy-corrected milk, and milk efficiency were similar. Key words: milk yield, milk composition, sweet sorghum silage
\end{abstract}

\section{Short Communication}

Forage sorghum is an important silage in several arid and semi-arid climatic regions and is well adapted to environments with limited rainfall, high temperatures, and low soil fertility. Forage sorghum utilizes water much more efficiently than corn, has higher biomass yield when exposed to drought and will still produce acceptable silage yields (Sanderson et al., 1992). Previous studies showed that lactating dairy cows fed normal forage sorghum consumed less DM and produced less milk than cows fed traditional forages such as corn and alfalfa silages (Grant et al., 1995; Oliver et al.,

Received August 30, 2011.

Accepted October 6, 2011.

${ }^{1}$ Corresponding author: arif.mustafa@mcgill.ca
2004). Reductions in DMI and milk yield ranged from 11.7 to $15.0 \%$ and from 8.3 to $27.1 \%$, respectively. The inferior performance of dairy cows fed normal sorghum was attributed mainly to greater NDF intake and reduced ruminal fiber digestion, which may result in increased rumen fill, reduced DMI, and less milk production (Nichols et al., 1998; Aydin et al., 1999). In North America, most forage sorghum production is found in the Midwest and the Plains regions of the United States. However, forage sorghum hybrids adapted to the growing conditions of southern Ontario and Quebec in Canada have recently been developed from Sudan type parents. A high water-soluble carbohydrate hybrid (CSSH45, $16.8^{\circ}$ Brix) has also been developed for ethanol and forage production. High water-soluble carbohydrates may improve ensilability of forages by accelerating lactic acid production (Adesogan et al., 2004). Our objectives were to determine the effects of feeding silage made from forage sorghum (with high water-soluble carbohydrate content) to lactating dairy cows on milk yield and composition and ruminal fermentation.

Forage sorghum (hybrid CSSH45) was seeded on June 3, 2009, and harvested at late milk stage of maturity on September 22, 2009. A second-cut alfalfa forage was harvested at the early bloom stage and wilted to a targeted $30 \%$ DM. All forages were chopped to a theoretical cut length of $8 \mathrm{~mm}$ with a forage harvester and ensiled in tower silos for 3 mo.

Twelve lactating Holstein cows of mixed parities, in early to mid lactation (BW $713 \pm 48.1 \mathrm{~kg}, 88 \pm 34.8$ DIM) were blocked by parity and DIM, and divided into 2 equal groups. The cows were housed in tie stalls with free access to water. Two diets were formulated with a 50:50 forage:concentrate ratio to meet the nutrient requirements of dairy cows in early lactation (NRC, 2001). Sweet sorghum silage (SS) and alfalfa silage (AS) constituted $70 \%$ of the total forage in the first and second diets, respectively (Table 1). Diets were offered ad libitum as TMR twice daily at 0800 and $1600 \mathrm{~h}$. Experimental periods consisted of $14 \mathrm{~d}$ of diet adaptation and $10 \mathrm{~d}$ of data collection. Cows were milked twice daily at 0800 and $1600 \mathrm{~h}$, and daily milk 
Table 1. Ingredients and chemical composition of experimental diets

\begin{tabular}{|c|c|c|}
\hline \multirow[b]{2}{*}{ Item } & \multicolumn{2}{|c|}{ Silage } \\
\hline & $\begin{array}{l}\text { Sweet } \\
\text { sorghum }\end{array}$ & Alfalfa \\
\hline \multicolumn{3}{|l|}{ Ingredients, $\%$} \\
\hline Sorghum silage & 34.9 & \\
\hline Alfalfa silage & & 34.6 \\
\hline Corn silage & 10.1 & 10.1 \\
\hline Grass hay & 5.3 & 5.3 \\
\hline High-moisture corn & 30.5 & 34.6 \\
\hline Soybean meal & 11.7 & 8.6 \\
\hline Megalac $^{1}$ & 1.2 & 1.7 \\
\hline AminoPlus $^{2}$ & 3.6 & 3.6 \\
\hline Mineral $\operatorname{mix}^{3}$ & 0.8 & 0.5 \\
\hline Sodium bicarbonate & 0.8 & 0.4 \\
\hline Blue salt ${ }^{4}$ & 0.3 & 0.4 \\
\hline Limestone & 0.3 & 0.2 \\
\hline Urea & 0.5 & \\
\hline \multicolumn{3}{|l|}{ Chemical composition } \\
\hline DM, \% & $39.9 \pm 0.57$ & $49.0 \pm 0.99$ \\
\hline Ash, \% & $6.7 \pm 0.21$ & $7.2 \pm 0.36$ \\
\hline Ether extract, \% & $3.7 \pm 0.03$ & $3.8 \pm 0.11$ \\
\hline NDF, \% & $38.8 \pm 1.64$ & $31.1 \pm 0.86$ \\
\hline $\mathrm{ADF}, \%$ & $23.0 \pm 1.13$ & $21.1 \pm 0.12$ \\
\hline Acid detergent lignin, $\%$ & $2.3 \pm 0.11$ & $2.8 \pm 0.06$ \\
\hline Starch, \% & $25.5 \pm 2.66$ & $30.0 \pm 1.56$ \\
\hline Starch:NDF & $0.66 \pm 0.157$ & $0.96 \pm 0.036$ \\
\hline $\mathrm{CP}, \%$ & $16.4 \pm 0.46$ & $18.0 \pm 0.70$ \\
\hline Soluble protein, $\%$ of $\mathrm{CP}$ & $31.6 \pm 0.22$ & $40.5 \pm 3.39$ \\
\hline Neutral detergent insoluble CP, $\%$ of $\mathrm{CP}$ & $16.8 \pm 0.95$ & $12.6 \pm 2.19$ \\
\hline Acid detergent insoluble $\mathrm{CP}, \%$ of $\mathrm{CP}$ & $5.4 \pm 0.74$ & $5.9 \pm 0.79$ \\
\hline $\mathrm{NE}_{\mathrm{L}},{ }^{5} \mathrm{Mcal} / \mathrm{kg}$ & $1.59 \pm 0.008$ & $1.62 \pm 0.014$ \\
\hline \multicolumn{3}{|c|}{$\begin{array}{l}{ }^{1} \text { Ca salts of palm fatty acids (Church and Dwight Co. Inc., Princeton, NJ). } \\
\text {. }\end{array}$} \\
\hline \multicolumn{3}{|c|}{${ }^{2}$ Contained $50.5 \% \mathrm{CP}, 20 \% \mathrm{NDF}, 8 \% \mathrm{ADF}, 1.4 \%$ ether extract, $0.42 \% \mathrm{Ca}$, and $0.7 \% \mathrm{P}$. } \\
\hline \multirow{2}{*}{\multicolumn{3}{|c|}{$\begin{array}{l}{ }^{3} \mathrm{Contained} \text { per kilogram: } 4.5 \% \mathrm{Ca}, 2.5 \% \mathrm{P}, 6.6 \% \mathrm{Na}, 1.5 \% \mathrm{Mg}, 1.2 \% \mathrm{~K}, 0.11 \% \mathrm{~S}, 1,372 \mathrm{mg} \text { of Fe, } 1,032 \mathrm{mg} \text { of } \\
\mathrm{Mn}, 1,500 \mathrm{mg} \text { of } \mathrm{Zn}, 247 \mathrm{mg} \text { of } \mathrm{Cu}, 16 \mathrm{mg} \text { of I, } 16 \mathrm{mg} \text { of } \mathrm{Co}, 10 \mathrm{mg} \text { of Se, } 185,000 \mathrm{IU} \text { of vitamin A, 32,500 IU } \\
\text { of vitamin } \mathrm{D}_{3} \text {, and } 900 \mathrm{IU} \text { of vitamin E. }\end{array}$}} \\
\hline \multirow{2}{*}{\multicolumn{3}{|c|}{${ }^{4}$ Contained $99 \% \mathrm{NaCl}, 400 \mathrm{mg}$ of $\mathrm{Co} / \mathrm{kg}$, and $70 \mathrm{mg}$ of $\mathrm{I} / \mathrm{kg}$. }} \\
\hline $50 \mathrm{C}=\mathrm{l}$ & & \\
\hline
\end{tabular}

samples were pooled according to milk yield at each milking. Diets were sampled 3 times per period and composited by period. The composited feed samples were oven-dried at $60^{\circ} \mathrm{C}$ for $72 \mathrm{~h}$, ground through a 1-mm screen, and stored at room temperature for later analysis. Orts were measured daily to determine daily intake for each cow. Extracts from SS and AS were analyzed for water-soluble carbohydrates (Dubois et al., 1956) and organic acids (Mullin and Emmons, 1997). Ground feed and silage samples were analyzed for DM, ash, acid detergent lignin, and ether extract using standard procedures (AOAC, 1990). Neutral detergent fiber (Van Soest et al., 1991) and ADF (AOAC, 1990) were determined using an Ankom Fiber analyzer (Ankom Technology Corp., Macedon, NY). Crude protein (N $\times 6.25)$ was measured using a Leco Nitrogen analyzer (FP-428 Nitrogen Determinator, Leco Corp., St. Joseph, MI). Starch content of diets and silages was determined according to McCleary et al. (1997). Soluble protein and NPN were determined according to Licitra et al. (1996), whereas acid and neutral detergent insoluble protein were determined by analyzing ADF and NDF residues for total N. Milk samples were analyzed for fat, protein, lactose, and MUN using an infrared analyzer (MilkoScan, model Foss 4000, Foss Food Technology, Hillerød, Denmark). Milk TS were determined according to AOAC (1990).

Data from the production study were analyzed using PROC MIXED (SAS Institute, 1989) for a crossover design. The model included effects of cow, treatment, sequence, parity, and period. Significant differences were declared at $P<0.05$.

Chemical composition of $\mathrm{SS}$ and $\mathrm{AS}$ is shown in Table 2. Relative to AS, SS contained $58 \%$ more NDF and 36.6 and $72.7 \%$ less acid detergent lignin and CP, respectively. Data regarding the chemical composition of SS are unavailable. However, our CP values were similar, whereas NDF and ADF values were higher 
Table 2. Chemical composition of sweet sorghum silage and alfalfa silage

\begin{tabular}{lcc}
\hline & \multicolumn{2}{c}{ Silage } \\
\cline { 2 - 3 } & \multicolumn{2}{c}{ Sweet } \\
Item & $24.9 \pm 1.06$ & Alfalfa \\
\hline DM, \% & $3.81 \pm 0.085$ & $46.4 \pm 0.92$ \\
pH & $3.6 \pm 0.49$ & $4.75 \pm 0.099$ \\
Lactic acid, ${ }^{1} \%$ & $2.8 \pm 0.27$ & $2.5 \pm 0.69$ \\
Acetic acid, ${ }^{\%}$ & $2.8 \pm 0.27$ & $0.9 \pm 0.27$ \\
Water-soluble carbohydrates, \% & $6.3 \pm 0.03$ & $1.0 \pm 0.71$ \\
Ash, \% & $1.6 \pm 0.21$ & $10.3 \pm 0.41$ \\
Ether extract, \% & $61.4 \pm 1.90$ & $2.2 \pm 0.25$ \\
NDF, \% & $39.2 \pm 0.13$ & $47.4 \pm 1.37$ \\
ADF, \% & $3.8 \pm 0.82$ & $38.9 \pm 0.52$ \\
Acid detergent lignin, \% & $5.1 \pm 0.08$ & $6.0 \pm 0.15$ \\
Starch, \% & $6.7 \pm 0.07$ & $0.5 \pm 0.11$ \\
CP, \% & $51.3 \pm 1.51$ & $24.6 \pm 0.06$ \\
Soluble protein, \% of CP & $21.2 \pm 0.89$ & $66.1 \pm 1.11$ \\
Neutral detergent insoluble protein, \% of CP & $8.4 \pm 0.92$ & $11.9 \pm 3.26$ \\
Acid detergent insoluble protein, \% of CP & $1.38 \pm 0.009$ & $6.6 \pm 0.68$ \\
NE ${ }_{\mathrm{L}}{ }^{2}$ Mcal/kg & & $1.38 \pm 0.014$ \\
\hline${ }^{1}$ Determined according to Mullin and Emmons (1997). & & \\
${ }^{1}$ Calculated according to Weiss et al. (1992). & &
\end{tabular}

than those previously reported for normal sorghum silage (as opposed to sweet sorghum silage; Aydin et al., 1999). Our NDF and ADF values were in good agreement with those reported by Grant et al. (1995) for normal sorghum.

Dry matter intake was similar for the 2 dietary treatments, whereas CP intake was greater for cows on the AS diet than for those on the SS diet (Table 3). However, cows fed the SS diet consumed more $(P<0.01)$ NDF than cows fed the AS diet, presumably because of the lower content of NDF in the AS diet (Table 3). Grant et al. (1995) found no differences in DMI, CP intake, or NDF intake between mid lactation cows fed normal sorghum silage and AS at $65 \%$ of dietary DM. However, Aydin et al. (1999) reported greater DMI (\% of BW) and less NDF intake for cows fed AS than for those fed normal sorghum silage. Cows fed normal sorghum silage diets consumed similar (Oliver et al., 2004) or less (Grant et al., 1995; Aydin et al., 1999) DM than those fed corn silage diets. For high-producing cows in early lactation, DMI may be limited by gut fill when diets containing more than $32 \%$ NDF are fed, which was not the case in our study (Mertens, 1994).

Cows fed AS produced more $(P=0.01)$ milk than cows fed SS (Table 3). Greater $\mathrm{NE}_{\mathrm{L}}$ for the AS than the SS diet (1.62 vs. 1.59) may help to explain the difference in milk yield. Yields of ECM, $4 \%$ FCM, and SCM were not affected by silage type, likely because of the greater $(P<0.01)$ fat concentration in the milk of cows fed SS than those fed AS. Milk yield and 4\% FCM were 17 to $48 \%$ and 18 to $37 \%$, respectively, greater for cows fed AS than for those fed normal sorghum silage (Grant et al., 1995; Aydin et al., 1999). Similar findings have been reported when performance of dairy cows fed normal sorghum silage was compared with that of cows fed corn silage (Grant et al., 1995; Aydin et al., 1999; Oliver et al., 2004). In those studies, cows fed normal sorghum silage consumed more dietary NDF than those fed AS or corn silage. However, when fed at equal concentrations of dietary NDF, sorghum silage supported similar DMI and milk yield to tropical corn silage (Nichols et al., 1998).

Intake of dietary NDF is a major factor that limits milk production of dairy cows, particularly in early lactation when DMI is often limited by rumen fill. Mertens (1994) suggested that cows should be able to consume $1.1 \%$ of their BW/d as NDF without limiting milk production, which is in agreement with the consumption of cows fed the AS diet in the current study. In the present study, milk yield was reduced by $4 \mathrm{~kg} / \mathrm{d}$ when dietary NDF intake increased from 1.01 to $1.34 \%$ of BW (Table 3).

Because of the unexpected low CP content of SS, the SS diet contained $8.9 \%$ less $\mathrm{CP}$ than the AS diet (Table 1). Feeding diets deficient in $\mathrm{CP}$ and RDP content may negatively affect $4 \%$ FCM, ECM, and fat and protein concentrations (Broderick, 2003; Kalscheur et al., 2006). However, these negative effects were not observed in our study, suggesting that the lower DMI and milk yield associated with feeding SS was not due to the reduced dietary CP content. Broderick (2003) concluded that feeding $16.7 \% \mathrm{CP}$ was adequate for supporting milk production in high-producing dairy cows.

Milk fat and TS concentrations were greater $(P<$ $0.01)$, whereas milk lactose $(P=0.01)$ and $\operatorname{SNF}(P=$ 0.01 ) concentrations were less in the milk of cows fed 
Table 3. Performance of dairy cows fed sweet sorghum silage and alfalfa silage

\begin{tabular}{|c|c|c|c|c|}
\hline \multirow[b]{2}{*}{ Item } & \multicolumn{2}{|c|}{ Diet } & \multirow[b]{2}{*}{$\mathrm{SEM}^{1}$} & \multirow[b]{2}{*}{$P$-value ${ }^{2}$} \\
\hline & $\begin{array}{l}\text { Sweet sorghum } \\
\text { silage }\end{array}$ & $\begin{array}{l}\text { Alfalfa } \\
\text { silage }\end{array}$ & & \\
\hline \multicolumn{5}{|l|}{ Intake } \\
\hline $\mathrm{DM}, \mathrm{kg} / \mathrm{d}$ & 24.8 & 25.1 & 0.99 & 0.66 \\
\hline DM. $\%$ of $B W$ & 3.48 & 3.52 & 0.09 & 0.73 \\
\hline $\mathrm{CP}, \mathrm{kg} / \mathrm{d}$ & 4.0 & 4.7 & 0.16 & $<0.01$ \\
\hline $\mathrm{NDF}, \mathrm{kg} / \mathrm{d}$ & 9.6 & 7.9 & 0.29 & $<0.01$ \\
\hline NDF, $\%$ of $B W$ & 1.34 & 1.09 & 0.04 & $<0.01$ \\
\hline \multicolumn{5}{|l|}{ Milk composition, $\%$} \\
\hline Fat & 4.44 & 3.80 & 0.204 & $<0.01$ \\
\hline $\mathrm{CP}$ & 3.19 & 3.24 & 0.081 & 0.22 \\
\hline Lactose & 4.55 & 4.61 & 0.038 & 0.01 \\
\hline TS & 13.31 & 12.88 & 0.266 & $<0.01$ \\
\hline SNF & 8.88 & 9.08 & 0.097 & 0.01 \\
\hline MUN, mg/dL & 10.0 & 14.0 & 0.51 & $<0.01$ \\
\hline \multicolumn{5}{|l|}{ Yield, $\mathrm{kg} / \mathrm{d}$} \\
\hline Milk & 33.0 & 36.8 & 2.06 & 0.01 \\
\hline ECM & 37.1 & 37.6 & 1.52 & 0.76 \\
\hline SCM & 34.9 & 35.7 & 1.44 & 0.65 \\
\hline $4 \% \mathrm{FCM}$ & 35.3 & 35.0 & 1.42 & 0.84 \\
\hline Fat & 1.43 & 1.36 & 0.043 & 0.06 \\
\hline $\mathrm{CP}$ & 1.06 & 1.18 & 0.051 & 0.06 \\
\hline Lactose & 1.52 & 1.69 & 0.094 & 0.04 \\
\hline TS & 4.43 & 4.67 & 0.208 & 0.26 \\
\hline $\mathrm{SNF}$ & 2.97 & 3.32 & 0.175 & 0.04 \\
\hline Milk efficiency, ECM/DMI & 1.53 & 1.50 & 0.041 & 0.60 \\
\hline
\end{tabular}

${ }^{1}$ Pooled standard error of the mean.

${ }^{2} P$-values for treatment effects.

the SS diet than in the milk of cows fed the AS diet (Table 3). However, the concentration of milk protein was not affected by silage type. The ratio of starch:NDF was lower for the SS than the AS diet (Table 1), which may explain the difference in milk fat concentrations between dietary treatments. Beckman and Weiss (2005) reported a negative linear relationship between milk fat concentration and the dietary starch:NDF ratio. Data regarding effects of feeding regular sorghum silage on milk composition are inconsistent. Feeding sorghum silage relative to AS decreased milk fat and milk lactose concentrations in some studies (Grant et al., 1995) but not others (Aydin et al., 1999). The concentration of MUN was greater $(P<0.01)$ in the milk of cows fed AS than in the milk of cows fed SS (Table 3). Greater MUN is expected for high CP diets (Broderick, 2003).

Under the conditions of our study, feeding SS compared with AS decreased the milk yield of dairy cows, likely because of the increased dietary NDF content. However, ECM, 4\% FCM, and SCM were not influenced by silage type. The reduction in MUN and ruminal ammonia concentration associated with feeding SS were likely due to the unexpected low $\mathrm{CP}$ content of the sweet sorghum silage diet. To improve DMI, SS should be fed at levels lower than that used in the present study.

\section{REFERENCES}

Adesogan, A. T., N. Krueger, M. B. Salawu, D. B. Dean, and C. R. Staples. 2004. The influence of treatment with dual purpose bacterial inoculants or soluble carbohydrates on the fermentation and aerobic stability of Bermudagrass. J. Dairy Sci. 87:3407-3416.

AOAC. 1990. Official Methods of Analysis. 15th ed. Vol. 1. Assoc. Off. Anal. Chem., Arlington, VA.

Aydin, G., R. J. Grant, and J. O'Rear. 1999. Brown midrib sorghum in diets for lactating dairy cows. J. Dairy Sci. 82:2127-2135.

Beckman, J. L., and W. P. Weiss. 2005. Nutrient digestibility of diets with different fiber to starch ratios when fed to lactating dairy cows. J. Dairy Sci. 88:1015-1023.

Broderick, G. A. 2003. Effects of varying dietary protein and energy levels on the production of lactating dairy cows. J. Dairy Sci. 86:1370-1381.

Dubois, D. G., K. A. Gilles, J. K. Hamilton, P. A. Rebers, and F. Smith. 1956. Colorimetric method for determination of sugars and related substances. Anal. Chem. 28:350-356.

Grant, R. J., S. G. Haddad, K. J. Moore, and J. F. Pedersen. 1995. Brown midrib sorghum silage for midlactation dairy cows. J. Dairy Sci. 78:1970-1980.

Kalscheur, K. F., R. L. Baldwin VI, B. P. Glenn, and R. A. Kohn. 2006. Milk production of dairy cows fed differing concentrations of rumen-degraded protein. J. Dairy Sci. 89:249-259.

Licitra, G., T. M. Hernandez, and P. J. Van Soest. 1996. Standardization procedures for nitrogen fractionation of ruminant feeds. Anim. Feed Sci. Technol. 57:347-358.

McCleary, B. V., T. S. Gibson, and D. C. Mugford. 1997. Measurement of total starch in cereal products by amyloglucosidase- $\alpha$ amylase method: Collaborative study. J. AOAC Int. 80:571-579.

Mertens, D. R. 1994. Regulation of forage intake. Pages 450-493 in Forage Quality, Evaluation and Utilization. C. G. Fahey Jr., M. Collins, D. R. Mertens, and L. D. Mosser, ed. Am. Soc. Agron., Crop Sci. Soc. Am., and Soil Sci. Soc. Am., Madison, WI. 
Mullin, W. J., and D. B. Emmons. 1997. Determination of organic acids and sugars in cheese, milk and whey by high performance liquid chromatography. Food Res. Int. 30:147-151.

Nichols, S. W., M. A. Froetschel, H. E. Amos, and L. O. Ely. 1998. Effects of fiber from tropical corn and forage sorghum silages on intake, digestion, and performance of lactating dairy cows. J. Dairy Sci. 81:2383-2393.

NRC. 2001. Nutrient Requirements of Dairy Cattle. National Academy Press, Washington, DC.

Oliver, A. L., R. J. Grant, J. F. Pedersen, and J. O'Rear. 2004. Comparison of brown midrib- 6 and -18 forage sorghum with conventional sorghum and corn silage in diets of lactating dairy cows. J. Dairy Sci. 87:637-644
Sanderson, M. A., R. M. Jones, J. Ward, and R. Wolfe. 1992. Silage sorghum performance trial as Stephensville: Forage Research in Texas. Report PR-5018. Texas Agric. Exp. Stn., Stephensville.

SAS Institute. 1989. SAS/STAT User's Guide: Statistics. SAS Inst. Inc., Cary, NC.

Van Soest, P. J., P. J. Robertson, and B. A. Lewis. 1991. Methods for dietary fiber, neutral detergent fiber, and nonstarch polysaccharides in relation to animal nutrition. J. Dairy Sci. 74:3583-3597.

Weiss, W. P., H. R. Conrad, and N. R. St. Pierre. 1992. A theoretically based model for predicting total digestible nutrient values of forages and concentrates. Anim. Feed Sci. Technol. 39:95-110. 